\title{
Gaya Kepemimpinan Entreprenuer dalam Gereja Masa Kini
}

\section{Tony Tedjo', Josef Christianto², Michael Dendi Tinggogoy33, Sendi Gunarto4, Yelmima Kadera ${ }^{5}$ \\ STT Kharisma ${ }^{1}$, STT Kharisma ${ }^{2}$, STT Kharisma ${ }^{3}$, STT Kharisma ${ }^{4}$, STT Kharisma ${ }^{5}$ email korespondensi: tonytedjo@gmail.com}

\begin{abstract}
Church leaders are one of the main reasons that decide the church will be successful or not. Church leaders nowadays are requested to operate their leadership in such a way to answer every problems that happen on these days. One of the problems faced today is the lack of job opportunities as a result of the ongoing pandemic. The church as a social institution is asked to play an active role in helping to overcome this problem. Therefore we need a leadership style that is able to overcome these problems. In this paper, I will use a qualitative method by reviewing various literature sources to find a leadership style that fits the current context. Entrepreneur leadership style is one of many leadership styles that can be an option to solve any problems that churches are facing nowadays. Entrepreneur leadership style will create many jobs dan surely is going to solve this problems that happen during this pandemic
\end{abstract}

Keywords: Church leaders, leadership style, entrepreneur

Abstrak: Pemimpin gereja merupakan salah satu alasan utama yang menentukan berhasil atau tidaknya sebuah gereja. Pemimpin gereja masa kini diminta untuk menjalankan kepemimpinannya sedemikian rupa untuk menjawab setiap permasalahan yang ada saat ini. Salah satu permasalahan yang dihadapi saat ini adalah adalah minimnya ketersediaan lapangan pekerjaan sebagai dampak dari pandemi yang sedang terjadi. Gereja sebagai salah satu lembaga sosial diminta untuk berperan aktif membantu mengatasi hal tersebut. Oleh sebab itu diperlukan sebuah gaya kepemimpinan yang mampu mengatasi permasalahan tersebut. Dalam tulisan ini penulis akan menggunakan metode kualitatif dengan mengkaji berbagai sumber literature untuk menemukan gaya kepemimpinan yang sesuai dengan konteks masa kini. Gaya kepemimpinan entrepreneur adalah salah satu gaya kepemimpinan yang dapat dijadikan opsi untuk mengatasi berbagai macam permasalahan dalam gereja pada masa kini. Gaya kepemimpinan entrepreneur akan membuka lapangan pekerjaan baru dan tentu saja akan membantu menyelesaikan masalah yang sedang dihadapi di masa pandemi ini.

Kata kunci: pemimpin gereja, gaya kepemimpinan, entrepreneur

Article History

\begin{tabular}{|l|l|l}
\hline Submitted: 1 Juni 2021 & Revised: 31 Juli 2021 & Accepted: 31 Juli 2021
\end{tabular}

\section{PENDAHULUAN}

Kepemimpinan adalah salah satu topik paling tua karena isu kepemimpinan sudah ada semenjak umat manusia ada di bumi ini. Sejak kehidupan manusia pertama yaitu Adam, Allah telah menjadikannya sebagai pemimpin atas ciptaan-ciptaan lainnya. Jadi bisa dikatakan bahwa usia kepemimpinan hampir setua usia umat manusia itu sendiri. Dengan usia yang telah begitu tua, masalah kepemimpinan nampaknya belum menghasilkan sebuah pakem yang yang dapat dijadikan standar bagi kepemimpinan yang ideal. Dalam kepempimpinan, terdapat banyak sekali gaya 
kepemimpinan di dalamnya yang tentu saja masing-masing dari gaya kepemimpinan ini memiliki kelebihan dan kekurangan mereka masing-masing.

Dunia mengenal banyak sekali gaya kepemimpinan. Green dan Vroon Yepton menjelaskan setidaknya ada empat gaya kepemimpinan di dunia ini yaitu (1) autokrasi, pemimpin mengambil semua keputusan dan bertanggung jawab pada dirinya sendiri. Gaya kepemimpinan ini cocok untuk memimpin orang-orang yang malas bekerja, mempunyai karakter yang perlu diawasi, dan kurang berinisiatif. (2) paternalistik, gaya kepemimpinan jenis ini mirip dengan gaya kepemimpinan autokrasi dimana para bawahan diminta untuk melakukan apa saja yang diinginkan oleh pemimpin karena apa yang pemimpin inginkan adalah yang terbaik. Gaya kepemimpinan jenis ini sering diterapkan dalam menjalani bisnis keluarga. (3) demokrasi, pemimpin disini berfungsi sebagai katalisator dalam pengambilan keputusan dan berbagi tanggung jawab bersama. Gaya kepemimpinan ini juga disebut dengan gaya kepemimpinan partisipatif. Gaya kepemimpinan ini cocok untuk mereka yang memiliki karakter senang bekerja, rajin, bertanggung jawab, dan memiliki inisiatif. (4) Laissez faire, disini pemimpin menyerahkan semua keputusan dan tanggung jawab yang ada pada bawahannya. Gaya kepemimpinan ini cocok diterapkan kepada bawahan yang memiliki karakter pekerja keras, berkompeten, bertanggung jawab dan berinisiatif (Pasande, 2020).

Menurut Hersey dan Blanchard, pada hakikatnya tidak ada satu pun gaya kepemimpinan yang paling baik. Gaya kepemimpinan haruslah ditentukan oleh situasi tertentu seperti kekuasaan yang dimiliki, kompleksitas tugas, dan kematangan bawahan itu sendiri. Gaya kepemimpinan situasional ini ditentukan oleh dua faktor utama yaitu (1) kemampuan, yakni keterampilan dan pengetahuan pekerjaan dan (2) motivasi, yakni motif pendorong agar seseorang mau bekerja (Pasande, 2020). Untuk gaya kepemimpinan situasional ini sendiri digolongkan lagi kedalam empat kelompok antara lain (1) delegatif, perliaku pemimpin dengan dukungan dan hubungan rendah dan pengarahan dan orientasi tugas pun rendah. (2) partisipatif, perilaku pemimpin yang mendukung hubungan tinggi dan pengarahan serta orientasi tugas yang rendah. Gaya kepemimpinan ini dapat diterapkan jika memiliki tingkat kematangan dan kedewasaan bawahan yang cukup matang dan cukup dewasa. (3) bimbingan, perilaku pemimpin dengan pengarahan dan orientasi hubungan tinggi dan pendampingan tingkat tinggi. Gaya kepemimpinan ini dapat diterapkan jika memiliki tingkat kematangan dan kedewasaan bawahan yang sudah bertumbuh. (4) pengarahan, perilaku pemimpin dengan dukungan dan orientasi yang rendah dan pengarahan serta 
orientasi tugas yang tinggi. Gaya kepemimpinan ini dapat digunakan jika bawahan belum memiliki kematangan dan kedewasaan (Pasande, 2020).

Ditengah banyaknya gaya kepemimpinan yang terdapat dalam dunia ini, artikel ini dimaksudkan untuk memberikan sudut pandang baru mengenai apa yang dimaksud dengan gaya kepemimpinan yang bersifat entrepreneur. Khususnya, gaya kepemimpinan entrepreneur ini akan ditinjau dari sudut pandang rohani. Apa itu kepemimpinan? Apa yang dimaksud dengan entrepreneur? Apakah gaya kepemimpinan entrepreneur ini merupakan salah satu contoh gaya kepemimpinan yang efektif untuk diterapkan dalam gereja masa kini? Artikel ini akan membahas itu semua dan akan menyimpulkan apakah gaya kepemimpinan model entrepreneur ini layak untuk diterapkan dalam kehidupan gereja masa kini.

\section{METODE}

Metode yang penulis gunakan dalam penulisan artikel ini adalah penelitian kualitatif dimana penulis mengkaji berbagai sumber tertulis yang ada baik itu buku, ebook, ataupun jurnal dalam rangka menyusun artikel ini. Penulis mencari beragam sumber tertulis yang valid yang dapat dijadikan acuan dalam penulisan artikel ini.

\section{HASIL DAN PEMBAHASAN}

\section{Definisi Kepemimpinan}

Kepemimpinan (leadership) selalu berkaitan dengan seseorang yang dapat memberikan pengaruh bagi perilaku orang lain guna mencapai suatu tujuan. Dengan kekuasaan, pemimpin dapat memberikan pengaruh terhadap perilaku bawahannya. Wilayah kekuasaan sendiri dapat dibagi menjadi lima bagian antara lain (1) kekuasaan keahlian (expert power), (2) kekuasaan legitimasi (legitimate power), (3) kekuasaan referensi (referent power), (4) kekuasaan penghargaan (reward power), dan (5) kekuasaan paksaan (coercive power) (Fridayana Yudiaatmaja, 2013).

Kadarusman berpendapat bahwa kepemimpinan (leadership) dapat dibagi menjadi tiga segmen yaitu (1) self leadership, (2) team leadership, (3) organizational leadership. Self leadership adalah mereka yang dapat memimpin dirinya sendiri sehingga dapat meraih keberhasilan dalam hidupnya. Team leadership dapat diartikan sebagai memimpin orang lain. Pemimpinnya akan dikenal dengan istilah team leader (pemimpin tim) yang mengerti apa yang menjadi tanggung jawab bawahannya, memahami kondisi bawahannya, bersedia untuk mengorbankan diri dengan tuntutan serta konsekuensi dari tanggung jawab yang dipikul, juga mempunyai komitmen untuk 
membuat setiap bawahannya mengembangkan kapasitas diri mereka masing-masing sehingga dapat menciptakan prestasi tertinggi yang dapat diraih. Organizational leadership dilihat dalam konteks suatu organisasi yang dipimpin oleh organizational leader (pemimpin organisasi) yang dapat mengerti nafas bisnis dari perusahaan yang dipimpinnya, membuat visi dan misi pengembangan bisnisnya, bersedia untuk mengorbankan diri dengan tuntutan dan konsekuensi tanggung jawab sosial, juga komitmen yang tinggi untuk membuat perusahaan yang dipimpinnya menjadi berkat bagi komunitas baik bagi komunitas lokal, nasional, maupun internasional (Fridayana Yudiaatmaja, 2013).

Kepemimpinan juga erat kaitannya dengan manajemen. Dua hal ini tidak dapat dipisahkan karena tentu saja dalam kepemimpinan terdapat manajemen. Seorang pemimpin harus dapat melakukan aktivitas manajemen berupa merencanakan (planning), mengarahkan (leading), mengorganisasikan (organizing), dan mengendalikan (controlling). John Kotter, seorang dari Harvard Business School menyampaikan pendapatnya. la mengatakan bahwa manajemen berbicara tentang mengatasi kerumitan, sedangkan kepemimpinan berbicara tentang mengatasi perubahan (Fridayana Yudiaatmaja, 2013). Mullins juga berpendapat bahwa manajemen berkaitan dengan perencanaan, pengorganisasian, pengarahan, dan pengendalian aktivitas-aktivitas yang dilaksanakan oleh bawahannya sedangkan kepemimpinan lebih menekankan pada komunikasi, memotivasi dan memberi semangat kepada bawahan agar bertindak secara maksimal demi mencapai suatu tujuan (Fridayana Yudiaatmaja, 2013).

Seorang Kristen dapat mengetahui bahwa ia memang dipanggil Allah untuk menjadi pemimpin rohani dari beberapa hal berikut antara lain (1) la dapat merasakan panggilan Allah bagi dirinya untuk menjadi pemimpin pada bidang pelayanan khusus. (2) la menemukan dirinya berada dalam kondisi tidak dapat ditolak dan tidak dapat disangkali, bahwa ada dorongan kuat dari Allah dan ada bukti nyata tentang panggilan tentang tugas kepemimpinan. (3) la harus memastikan bahwa dirinya memiliki pikiran seorang pemimpin, karena nantinya ia harus bertanggung-jawab untuk berpikir, bersikap, dan bertindak sebagai pemimpin. (4) la memiliki pengaruh dan kemampuan memberi pertimbangan, guna menopang keputusan yang bijak dalam kinerja kepemimpinan. (5) la tergolong dalam kelompok pemimpin-pemimpin yang dibuktikan dengan pengalaman dan kuasa kepemimpinan yang ada padanya. (6) la harus memperoleh dukungan resmi sebagai tanda secara de facto dan memiliki tugas, kewenangan, hak, kewajiban, tanggung jawab dan pertanggungjawaban 
kepemimpinan. (7) la memiliki kekuatan dari dalam yang memberi kepastian akan integritas, kapasitas, dan kapabilitas kepemimpinan. (8) la terbukti sangat menyukai kepemimpinan sebagai bagian dari karir yang dikaruniakan Tuhan kepadanya.

\section{Definisi Entrepreneur}

Kata entrepreneur adalah padanan dari kata entrepreneur (bahasa Inggris) yang berasal dari bahasa Prancis entreprendre yang sudah dikenal sejak abad ke- 17. Sebagaimana yang dikutip oleh Arman Hakim menurut The Concise Oxford French Dictionary mengartikan enterprendre sebagai to undertake (menjalankan, melakukan, berusaha), to set about (memulai, menentukan), to begin (memulai) dan to attempt (mencoba, berusaha) (Hakim, 2007). Lebih lanjut Moh Yunus menegaskan bahwa Entrepreneur (wirausaha) berasal dari dari bahasa prancis entrependre yang berarti mengambil pekerjaan (to undertake) (Yunus, 2009). Entrepreneur diartikan juga sebagai orang yang memulai (The Originator) sesuatu bisnis baru yang berupaya memperbaiki sebuah unit keorganisasian melalui serangkaian perubahan-perubahan produktif (Winardi, 2015). Kewirausahaan adalah suatu sikap jiwa dan kemampuan untuk menciptakan sesuatu yang baru, yang sangat bernilai dan berguna, baik bagi dirinya sendiri maupun bagi orang lain (Wibowo, 2011).

Pengertian wirausaha di sini menekankan pada setiap orang yang memulai sesuatu bisnis yang baru. Sedangkan proses kewirausahaan meliputi semua kegiatan fungsi dan tindakan untuk mengejar dan memanfaatkan peluang dengan menciptakan suatu organisasi (Alma, 2010). Menjadi seorang entrepreneur berarti memadukan perwatakan pribadi, keuangan dan sumber-sumber daya di dalam lingkungan. Menjadi entrepreneur berarti memiliki kemampuan menemukan dan mengevaluasi peluangpeluang, mengumpulkan sumber-sumber daya yang diperlukan dan bertindak untuk memperoleh keuntungan dari peluang-peluang itu. Para entrepreneur merupakan pemimpin dan mereka menunjukkan sifat kepemimpinan dalam pelaksanaan sebagian besar kegiatan-kegiatannya. Kata entrepreneur atau wirausaha dalam bahasa Indonesia merupakan gabungan dari kata wira (gagah, berani, perkasa) dan usaha (bisnis) sehingga istilah entrepreneur dapat diartikan sebagai orang yang berani atau perkasa dalam usaha atau bisnis. Entrepreneur merupakan daya pikir dan daya kerja seseorang dalam menciptakan peluang ekonomi untuk kesejahteraan dirinya dan masyarakat sekitar. Orang yang memiliki jiwa entrepreneur pandai melihat peluang kerja dan usaha serta menerjemahkannya menjadi usaha nyata yang memiliki nilai tambah dan berani menghadapi resiko usahanya. Entrepreneur merupakan sikap, 
mental dan perilaku yang melekat pada diri seseorang dalam menjalankan usaha dan kegiatan ekonomi lainnya untuk memenuhi kebutuhan dan kesejahteraan hidup dirinya dan masyarakat pada umumnya.

Istilah entrepreneurship sendiri diperkenalkan oleh Richard Cantillon yang merupakan seorang ekonom Irlandia yang tinggal di Prancis pada abad ke-18. Menurutnya, entrepreneurship dapat diartikan sebagai the agent who buy means of production at cerium prices in order to combine them into a new product. Dia mengatakan bahwa entrepreneur adalah seorang yang berani mengambil resiko. Lalu selang beberapa waktu kemudian, J.B. Say dari Prancis menyempurnakan definisi yang dipaparkan oleh Cantillon dan merumuskan pengertian entrepreneurship sebagai one who brings other people together ini order to build a single productive organism. Yang berarti bahwa seorang entrepreneur menempati fungsi yang lebih luas yakni seseorang yang mengorganisasikan orang lain untuk sebuah kegiatan yang bersifat produktif (Tanasyah et al., 2020)

Ada dua fungsi Entrepreneur dalam perekonomian antara lain, (1) secara makro, entrepreneur berperan dalam ekonomi nasional sebagai penggerak, pengendali dan pemacu perekonomian bangsa. Para entrepreneur berfungsi menciptakan investasi baru, membentuk modal baru, menghasilkan lapangan kerja baru, menciptakan produktivitas, meningkatkan ekspor, mendorong pertumbuhan ekonomi, mengurangi kesenjangan sosial dan meningkatkan kesejahteraan. (2) fungsi entrepreneur secara mikro, adalah mengkombinasikan sumber-sumber ekonomi ke dalam cara baru dan berbeda, menciptakan nilai tambah, menciptakan usaha-usaha baru dan menciptakan peluang-peluang baru (Suryana, 2013).

Dalam menjalankan fungsinya, secara umum entrepreneur memiliki dua peran yaitu (1) sebagai penemu, yaitu menemukan dan menciptakan produk baru, teknologi baru, ide-ide baru, dan organisasi usaha baru. (2) sebagai perencana, yaitu perencana perusahaan, strategi perusahaan, ide-ide dalam perusahaan, dan organisasi perusahaan (Suryana, 2013).

Thomas W. Zimmerer mendeskripsikan bahwa terdapat karakteristik yang cenderung ditunjukkan oleh seorang wirausahawan antara lain adanya rasa tanggung jawab dan selalu berkomitmen (desire for responsibility), memilih resiko yang moderat (preference for moderate risk), percaya diri terhadap kemampuan sendiri (confidence in their abality to success), menghendaki umpan balik, semangat dan kerja keras (high level of energy), berorientasi kedepan, memiliki keterampilan berorganisasi, dan menghargai prestasi (Zimmerer \& Scarborough, 1996). Sementara itu, Dun Steinhoff 
mengemukakan enam karakteristik yang diperlukan untuk menjadi wirausahawan yang berhasil antara lain a) Memiliki visi dan tujuan usaha yang jelas, b) Bersedia menanggung resiko waktu dan uang, c) Memiliki perencanaan yang matang dan mampu mengorganisasikannya, d) Bekerja keras sesuai tingkat kepentingannya, e) Mengembangkan hubungan dengan pelanggan, pemasok, pekerja dan pihak lain, dan f) Bertanggung jawab terhadap keberhasilan dan kegagalan (Steinhoff \& Burgess, 1993).

Karakteristik seorang entrepreneur antara lain a) Sikap yang proaktif dan inisiatif yang kuat dalam usaha dan mental, b) Komitmen yang kuat dalam menjalankan usaha dan kegiatan ekonomi lainnya. Pendidikan karakter pada dasarnya adalah pendidikan nilai. Karakter sering juga disebut value in action. Nilainilai kebaikan yang terinternalisasikan pada diri peserta didik itulah yang dapat menjadikan karakter baik. Menurut Kasmir pengertian entrepreneur adalah orang yang berjiwa berani mengambil resiko untuk membuka usaha dalam berbagai kesempatan (Handaru et al., 2015). Sedangkan menurut Zimmerer perngertian entrepreneur adalah suatu proses penerapan kreativitas dan inovasi dalam memecahkan persoalan dan menemukan peluang untuk memperbaiki kehidupan. Menurut Soeparman Spemahamidjaja pengertian entrepreneur adalah suatu kemampuan (ability) dalam berpikir kreatif dan berperilaku inovatif yang dijadikan dasar, sumber daya, tenaga penggerak tujuan, siasat, kiat dan proses dalam menghadapi tantangan hidup. Menjadi wirausahawan sukses merupakan dambaan kebanyakan orang, namun pada akhirnya hanya segelintir orang yang serius untuk melakukan aksi dapat mewujudkan impiannya menjadi pengusaha sukses. Resiko dan perencanaan yang terlalu lama seringkali menjadi penghambat seseorang untuk membangun dan memajukan usahanya. Sebagai langkah awal untuk membangun bisnis dan menjadi pengusaha sukses, seseorang harus menumbuhkan jiwa wirausaha dan langsung melakukan praktek membangun bisnisnya. Bakat entrepreneur bisa dikembangkan oleh siapa saja apapun latar belakang pendidikannya (Acs et al., n.d.).

\section{Teologi Entrepreneurship}

Permulaan penciptaan manusia menggambarkan bahwa manusia tidak saja sebagai ciptaan Tuhan yang tertinggi tetapi juga sebagai gambar dan rupa Allah itu sendiri. Manusia yang pada hakekatnya berkuasa atas ciptaaan Tuhan, diberikan mandat untuk memenuhi, menguasai, dan menaklukan ciptaan-ciptaan Allah lainnya. 
Hal pertama-tama tentang manusia yang ditulis dalam kitab Kejadian sebelum manusia jatuh dalam dosa adalah bahwa Tuhan merencanakan umat manusia memenuhi bumi dan menguasainya. Tuhan yang berkuasa merefleksikan diri-Nya secara khusus kepada ciptaan-Nya di dalam diri manusia dengan membuat manusia berkuasa dan dapat mencipta. Allah yang omnipresent telah mempresentasikan diriNya didalam bentuk manusia yang berbentuk dan dapat dijamah. Allah yang omniscience telah membagi pengetahuan-Nya kepada manusia sehingga manusia bisa mengusahakan tanah yang diberikan Tuhan. Allah yang omnipotent telah memberikan kuasa-Nya kepada manusia sehingga manusia bisa memilih dan mengambil keputusan bahwa ia berkuasa atas ciptaaan Tuhan. Allah yang omnibenevolence telah mengatakan bahwa seluruh ciptaan adalah baik bahkan manusia dikatakan sebagai ciptaan paling baik dan telah menciptakan tatanan moral bagi manusia. Berangkat dari pemahaman ciptaan semesta dan manusia, ada pekerjaan besar yang sedang direncakan dan dikerjakan Allah untuk ciptaan-Nya. Allah yang membuat alam semesta telah menempatkan manusia untuk memenuhi dan menguasai serta menaklukkan bumi. Hal ini menunjukkan suatu cara kerja keteraturan yang tertib dengan perencanaan teratur untuk mencapai suatu keinginan yang Allah ingin capai. Pemahaman akan entrepreneurship yang sangat identik dengan bisnis yang berkaitan dengan hukum untung dan rugi telah membuat kata entrepreneurship kehilangan makna yang sesungguhnya. Entrepreneurship yang sudah sering dikaitkan dengan para pengusaha berhasil atau para pelaku bisnis telah membuat kata ini menjadi eksklusif bagi kalangan dunia usaha atau orang yang mau berusaha.

Dalam refleksi teologis Kristen, entrepreneur Kristen diartikan sebagai seorang yang memiliki kreativitas dan inovasi yang dimotivasi oleh kasih dan disediakan khusus untuk melayani sesama dalam mengatasi masalah yang sesuai dengan prinsip-prinsip Alkitab. Artinya, entrepreneur tidak dapat dipisahkan dari kesaksian Alkitab itu sendiri. Akan tetapi Alkitab bukan kitab khusus tentang entrepreneur, melainkan firman Allah. Firman Allah adalah benar dan gagasan tentang entrepreneur tercantum dalam Alkitab. Kata entrepreneur tidak akan ditemukan dalam Alkitab tetapi ide dan praktik tentang entrepreneur disaksikan dalam Alkitab. Alkitab tidak memakai kata entrepreneur tetapi Alkitab memakai kata "segambar dan serupa". Oleh karena manusia dicipta segambar dan serupa dengan Tuhan, maka manusia memiliki kemampuan kreativitas dan inovatif. Narasi teks Kejadian 1:27 dan 2:15 menegaskan potensi entrepreneur dan perwujudan entrepreneur dalam diri manusia. Tuhan menempatkan manusia di taman Eden dengan kreativitas dan inovasi. 
Dalam Kejadian 2:15, Allah menyuruh manusia untuk mengusahakan dan memelihara taman itu. Menurut Brian Baugus, entrepreneurship is a creative act made possible by the creative impulse that God gave us. In addition, it requires certain personal traits that God desires us to have yang artinya adalah kewirausahaan sebagai tindakan kreatif dimungkinkan oleh dorongan kreatif yang diberikan Allah kepada manusia/orang percaya. Selain itu, memerlukan sifat-sifat pribadi tertentu bahwa Allah menginginkan orang percaya untuk memilikinya (Baugus, 2014).

Brian Baugus melanjutkan pendapatnya dengan menyatakan Scripture contains several cases of entrepreneurship, but we must first make sure that we are using the proper definition of the word. Entrepreneurship is a creative act that brings higher levels of satisfaction to people, results in more order, and finds ways to create greater value than existed before yang artinya adalah Alkitab berisi beberapa kasus kewirausahaan, tapi pertama-tama kita harus memastikan bahwa kita menggunakan definisi yang tepat dari kata itu. Kewirausahaan adalah tindakan kreatif yang membawa tingkat kepuasan kepada orang-orang, menghasilkan ketertiban, dan menemukan cara untuk menciptakan nilai lebih besar dari yang ada sebelumnya (Baugus, 2014).

Tomatala memakai istilah entrepreneur rohani untuk membedakannya dari entrepreneur umum. Entrepreneur rohani dalam konteks pembahasan Tomatala dalam bukunya yang berjudul "Spiritual Entrepreneurship: Anda Juga Bisa Menjadi Entrepreneur Rohani” tidak lain adalah entrepreneur Kristen. Dalam konteks Kristen, Dr. Yakob Tomatala menyatakan bahwa entrepreneur rohani (Kristen) adalah orang yang memiliki hubungan yang unik dengan Tuhan sebagai dasar kekuatan dan integritasnya dalam berusaha. Entrepreneur rohani (Kristen) adalah penyalur berkat Tuhan kepada orang lain yang ada disekitarnya. Menurut Tomatala, makna kata entrepreneurship menunjuk kepada kadar kemandirian tinggi, yang olehnya ada pikiran, keberanian untuk bertindak melaksanakan sesuatu secara mandiri dengan menggunakan cara unik sehingga mendatangkan kesuksesan, keberhasilan atau keberuntungan. Berdasarkan definisi ini, Tomatala mengarahkan penekanan pada kemandirian yang menjadi salah satu ciri entrepreneurship (Tomatala, 2010).

Berdasarkan fokus tersebut, Tomatala mengidentifikasi karakteristik seorang entrepreneur sebagai berikut a) Seorang entrepreneur memiliki kemandirian dalam berpikir unggul yaitu kemampuan berpikir tinggi untuk mengubah sesuatu menjadi peluang untuk sukses atau melalui kemampuan berpikir tinggi, seorang entrepreneur selalu berupaya untuk menangkap peluang, mencipta, mencari kesempatan dalam 
segala sesuatu, b) Seorang entrepreneur memiliki kemandirian dan keberanian dalam mengambil keputusan sekaligus berani menanggung resiko yang mungkin timbul atas keputusannya, c) Seorang entrepreneur memiliki kemandirian dalam kepiawaian merekayasa cara unggul untuk menangkap peluang usaha. Seorang entrepreneur memiliki karakteristik antara lain kemampuan berpikir unggul, bersikap berani, dan bertindak dengan cara unggul dalam menangani suatu upaya atau usaha mandiri (dalam berbagai bentuk) yang menyebabkan ia berhasil (Tomatala, 2010).

Entrepreneur Kristen adalah seorang yang memiliki kemampuan berpikir secara kreatif dan inovatif sehingga mampu mewujudkan cita-cita kreatifnya ke dunia nyata melalui inovasinya kepada kelompok Kristen yang sedang dipimpinnya. Seorang entrepreneur Kristen adalah seorang yang dalam kepemimpinannya mampu mengubah padang ilalang menjadi kota baru, mampu mengubah tempat pembuangan sampah menjadi resort yang indah. Entrepreneur Kristen bisa mengubah sebuah peluang menjadi tempat dimana orang lain dapat bekerja dan beraktivitas. Entrepreneur Kristen adalah orang yang mampu mengubah kotoran dan barang rongsokan menjadi emas bagi anggota gereja yang sedang dipimpinnya. Entrepreneur Kristen dicirikan dengan kemampuan inovatif dan kreatif dalam memimpin. Entrepreneur Kristen adalah kepemimpinan yang mampu mempersiapkan bawahan yang dipimpin untuk bekerja secara kreatif dan inovatif ketika nanti ia bekerja di tempat kerjanya dan mampu menciptakan lapangan kerja yang berguna bagi anggota jemaat agar mendapatkan tempat kerja yang memungkinkan. Pemimpin Kristen yang memiliki jiwa entrepreneur dapat mempersiapkan anggota gereja agar tidak memiliki mental mencari kerja tetapi menemukan atau menciptakan pekerjaan itu sendiri, bukan statis bekerja di sebuah tempat kerja tetapi mengembangkan semangat kerja secara kreatif dan inovatif. Tegasnya karena konteks yang sedang dihadapi gereja masa kini adalah sedikitnya kesediaan lapangan kerja yang tersedia sementara tenaga kerja sangat banyak jumlahnya, maka pemimpin entrepreneur Kristen memimpin warga gereja untuk memiliki dan mewujudkan mental menciptakan peluang kerja. Pemimpin yang tidak menumpuk di gereja tetapi pemimpin yang mampu merintis gereja lokal. Pemimpin yang tidak hanya melamar di gereja yang sudah ada tetapi pemimpin yang mampu memulai jemaat baru di tempat yang baru pula. Kepemimpinan entrepreneur Kristen memiliki inovasi dan kreativitas dalam berkhotbah yang disampaikan kepada jemaat. Kepemimpinan entrepreneur Kristen adalah kepemimpinan yang terbuka terhadap bantuan (dukungan) sebagaimana Paulus mendapat bantuan dana dari 
perempuan kaya pada zamannya. Tetapi juga berani memberdayakan kemampuannya sendiri yaitu membuat tenda untuk keperluannya demi eksistensi pelayanan yang dipercayakan Tuhan kepadanya. Kepemimpinan entrepreneur Kristen bukan pemimpin yang menggantungkan eksistensi pelayanannya pada pendapatan bulanan dari organisasi tetapi mampu berinovasi dan berkreasi mendapatkan pendapatan secara mandiri demi kelancaran pelayanan melalui kemampuan yang ada padanya. Paulus giat melaksanakan pekabaran Injil dan tentu saja hal ini membutuhkan sokongan dana dari pihak lain yang menaruh perhatian pada misi Kristus, tetapi Paulus juga secara alamiah memberdayakan kemampuan yang ia miliki yaitu membuat tenda. Hasilnya, Paulus tetap mempertahankan eksistensi pelayanannya sampai akhir hidupnya. Entrepreneur Kristen adalah proses mengarahkan perilaku orang lain kearah pencapaian suatu tujuan tertentu berdasarkan nilai-nilai Kristiani. Pengarahan dalam hal ini berarti menyebabkan orang lain bertindak dengan cara tertentu atau mengikuti arah tertentu yang tidak bertentangan dengan nilai-nilai Kristiani.

Kitab-kitab Injil juga membahas ide-ide dan konsep dari kepemimpinan entrepreneurship, sebab kitab-kitab ini menggambarkan kehidupan Sang Pemimpin Agung, yaitu Yesus Kristus. Siapa pun yang ingin berhasil dalam kepemimpinan yang sangat dibutuhkan gereja masa kini, ia mutlak harus belajar dengan rendah hati dari Tuhan Yesus sendiri. Kitab Kisah Para Rasul mencatat karya-karya para pemimpin gereja mula-mula seperti Petrus dan Paulus yang mengikuti setiap langkah Tuhan Yesus dalam kepemimpinan yang mereka jalankan. Kemudian dalam kitab-kitab Perjanjian Baru selanjutnya (terutama surat-surat), tidak dapat disangkal bahwa tulisan para rasul memperlihatkan karakter, kemampuan dan keterampilan mereka sebagai pemimpin gereja dalam mengatasi segala permasalahan yang terjadi pada jemaat mula-mula.

Meneliti pola kepemimpinan Tuhan Yesus dimulai ketika Yesus memanggil para murid-Nya, la berkata kepada mereka, "Mari, ikutlah Aku, dan kamu akan Kujadikan penjala manusia" (Mat. 4:19). Dalam panggilan ini didapati bahwa dalam pikiran-Nya ada dua prinsip kepemimpinan yang penting. Yang pertama adalah la mengajarkan fungsi kepemimpinan yang memimpin orang dari kerajaan kegelapan menuju kerajaan terang, dari belenggu dosa menuju kerajaan Allah yang sejati. Matthew Henry berkomentar bahwa sebagai penjala manusia para murid seharusnya menyelamatkan manusia, bukan menghancurkannya lalu seharusnya membawa mereka menuju ke tingkat yang lebih tinggi. Prinsip kedua adalah bahwa 
kepemimpinan harus dikembangkan. Yesus memanggil para murid sebab la menghendaki mereka mengikuti corak kepemimpinan-Nya, jadi la memanggil para murid untuk "mengikut Aku". Henry mengatakan bahwa Mereka harus memisahkan diri mereka agar terus hadir bersama dengan-Nya dan meneladani kerendahan hatiNya, harus mengikut Dia sebagai pemimpin mereka sebagaimana Yosua, dengan melayani Musa, dilayakkan untuk menjadi penerusnya (Henry, 1975).

Kepemimpinan Yesus adalah kepemimpinan yang mengacu kepada Kerajaan Allah. Kerajaan Allah atau Kerajaan Sorga merupakan titik tolak kepemimpinan Yesus semasa la berada di dunia. Pekabaran Kerajaan Allah tidak dilakukan Yesus di Yerusalem yang notabene merupakan pusat kekuasaan melainkan di Galilea yang merupakan lingkungan rakyat kecil. Konsep Kerajaan Allah sendiri diwarisi dari tradisi Perjanjian Lama yang berintikan pengakuan bahwa raja yang sebenarnya adalah Allah sendiri. Implikasi dari hal ini adalah bahwa semua raja manusia bukanlah penguasa mutlak yang berhak untuk menuntut ketundukan tanpa syarat. Oleh sebab itu, kekuasaan raja harus dibatasi dan dikontrol. Hanya Allah saja yang berhak atas ketaatan mutlak, sedangkan ketaatan terhadap raja manusia bersifat relatif (hanya dipenuhi selama raja menaati kehendak Allah dan menjalankan kekuasaannya di bumi dengan menjunjung tinggi nilai-nilai yang terkandung dalam Alkitab) (Wijaya, 2018)

Robert Coleman dalam bukunya "The Master Plan of Evangelism" memberikan delapan prinsip yang Yesus pakai dalam memperlengkapi para murid-Nya antara lain, pertama yaitu pemilihan. Yesus memilih sekelompok murid dari antara para pengikutNya untuk dilatih secara lebih efektif. Kedua yakni persekutuan. Yesus tinggal bersama mereka dalam suatu perkumpulan dan mereka mengikuti-Nya ke mana pun la pergi. la menghabiskan sebagian besar waktu-Nya untuk mengajar mereka. Ketiga adalah pengabdian. Yesus menuntut para murid-Nya untuk menaati-Nya. Ketaatan kepada-Nya merupakan bukti kepercayaan dan kasih mereka kepada-Nya. Taat berarti mereka harus siap membayar harga dalam mengikut Yesus dan Yesus sendiri memberikan kepada mereka suatu teladan ketaatan di atas kayu salib. Keempat yakni penyerahan diri. Yesus bukan hanya meminta mereka untuk taat, la sendiri menunjukkan bagaimana la mengasihi mereka melalui ucapan-Nya, "Gembala yang baik memberikan nyawanya bagi domba-dombanya” (Yoh. 10:11). Juga ketika la ditangkap, la berkata kepada para prajurit, "Jika Aku yang kamu cari, biarkanlah mereka ini pergi" (Yoh. 18:8). Kelima yaitu perwujudan. Semasa hidup-Nya bersama dengan para murid-Nya, la menunjukkan kepada mereka keagungan-Nya, sikap-Nya terhadap Allah Bapa, dan sikap-Nya terhadap manusia dalam pelayanan. Para murid 
belajar dari Yesus dengan melihat apa yang la lakukan. Keenam berupa pengutusan. Yesus tidak hanya mengajar dan menunjukkan bagaimana caranya untuk melayani, la juga memberi tugas yang harus dikerjakan oleh para murid-Nya dengan memberi mereka kesempatan untuk menerapkan apa yang telah mereka pelajari. Ketujuh yakni pembimbingan. Yesus mengevaluasi dan mengoreksi pelayanan para murid-Nya sehingga mereka bisa melayani secara lebih efektif. Ketika la menyembuhkan seorang anak laki-laki dari kerasukan setan sesudah peristiwa la berubah rupa, la menjelaskan kepada para murid-Nya bahwa mereka takkan mampu mengusir setan sebab mereka kurang beriman. la mengatakan bahwa mereka perlu meningkatkan waktu doa dan puasa mereka (Mrk. 9:28-29). Kedelapan adalah pelipatgandaan. Harapan Yesus dalam melatih para murid-Nya adalah agar mereka juga bisa menghasilkan muridmurid lainnya. Hal ini terlihat jelas dalam doa-Nya di dalam Yohanes 17:20, "Dan bukan untuk mereka ini saja Aku berdoa, tetapi juga untuk orang-orang yang percaya kepada-Ku oleh pemberitaan mereka." Itulah sebabnya ketika la siap berpisah dengan para murid-Nya, la mengingatkan mereka untuk memuridkan segala bangsa (Coleman, 2018).

Adam dan Hawa diberikan kuasa kepada mereka untuk berkembang dan menaklukkan bumi. Tugas yang sama diberikan kepada Nuh setelah air bah surut dan ketika Nuh keluar dari bahtera. Penetapan yang sama kepada Abraham ketika ia dipanggil menjadi bapa orang percaya sebab Abraham pergi ke tanah yang dijanjikan Tuhan sekalipun ia tidak mengetahuinya. Penyertaan Tuhan terhadap bangsa Yahudi untuk keluar dari tanah Mesir menuju ke tanah perjanjian yang dipimpin oleh Musa. Allah memanggil dari satu keluarga untuk membuat mereka menjadi bangsa yang besar dan menjadi Kerajaan Allah yang menghadirkan damai dan menunjukan siapa Allah kepada manusia di dalam dunia yang Allah ciptakan. Tokoh-tokoh Alkitab yang disebutkan dari Perjanjian Lama hingga Perjanjian Baru menunjukkan bahwa entrepreneurship adalah cara Allah untuk menjadikan sebuah bangsa menjadi besar. Keberhasilan Abraham dalam mengelola ternak dan hasil bumi, kesuksesan Yakub dalam berternak, kemahiran Yusuf mempersiapkan cadangan makanan pada masa kelaparan di Mesir telah membuat mereka tidak hanya selamat tetapi menjadi berkat bagi banyak orang dan suku disekitarnya. Inilah theology entrepreneurship tersebut bahwa Allah menghendaki manusia untuk mengusahakan apa yang telah diciptakanNya bukan untuk kepentingan sendiri tetapi kepentingan banyak orang supaya mereka dapat mengenal Allah yang benar. Theology entrepreneurship melihat dunia dalam perspektif utuh dan melihat manusia dalam kondisi komplit sehingga baik rohani 
dan jasmani adalah bagian yang saling membutuhkan dan saling mengisi. Theology entrepreneurship mengajak manusia untuk kembali kepada panggilan penciptaan yang diperbaharui didalam Kristus.

\section{KESIMPULAN}

Permasalahan gaya kepemimpinan khususnya kepemimpinan dalam gereja bukanlah sebuah masalah yang dapat dipandang sebelah mata. Berhasil atau tidaknya sebuah gereja salah satunya juga sangat dipengaruhi oleh gaya kepemimpinan dari pemimpin gereja tersebut. Gaya kepemimpinan entrepreneur tentu saja merupakan sebuah opsi yang menjanjikan pada saat ini. Gaya kepemimpinan ini menawarkan banyak sekali manfaat. Melalui gaya kepemimpinan entrepreneur, seorang pemimpin gereja akan dipacu untuk memiliki kreativitas dan inovasi dalam memimpin gerejanya. Hal ini akan membuat gereja yang dipimpin akan selalu bertumbuh dengan inovasi-inovasi kreatif yang lahir dari buah pemikiran sang pemimpin gereja tersebut. Gaya kepemimpinan model ini membuat pemimpin gereja dapat menyediakan lapangan pekerjaan bagi para jemaat-jemaat yang beribadah di gereja tersebut. Pemimpin entrepreneur diharuskan untuk mencari cara dalam menyediakan lapangan pekerjaan bagi para jemaatnya. Pemimpin entrepreneur tidak hanya diminta untuk mencukupi kebutuhan para jemaat dengan memberikan bantuan berupa subsidi dan hal-hal semacamnya tetapi lebih dari itu, pemimpin entrepreneur diminta untuk memberikan solusi yang lebih bersifat jangka panjang dibandingkan solusi yang sifatnya jangka pendek seperti bantuan langsung.

Gaya kepemimpinan entrepreneur merupakan pilihan yang relevan di masa kini karena pada masa kini, problema utama yang dihadapi para jemaat adalah terbatasnya lapangan pekerjaan. Gereja yang dapat menyediakan lapangan pekerjaan bagi para jemaatnya tentu saja dapat dikatakan sebagai gereja yang berhasil dalam menjawab permasalahan-permasalahan masa kini. Pemimpin gereja yang dapat menyediakan lapangan pekerjaan bagi para jemaatnya tentulah dapat disebut sebagai gembala yang berhasil dalam menjawab kebutuhan para domba-dombanya yang sedang kebingungan dengan minimnya lapangan pekerjaan yang tersedia.

\section{DAFTAR PUSTAKA}

Acs, Z. J., Sameeksha, A. E., Ae, D., \& Hessels, J. (n.d.). Entrepreneurship, economic development and institutions. https://doi.org/10.1007/s11187-0089135-9 
Alma, B. (2010). Kewirausahaan. Alfabeta.

Baugus, B. (2014). Entrepreneurship Within a Biblical Worldview. 1-35.

http://ifwe.s3.amazonaws.com/wp-content/uploads/2014/03/Entrepreneur-

Research-Paper1.pdf

Coleman, R. (2018). The Master Plan of Evangelism. Katalis Media.

Fridayana Yudiaatmaja. (2013). Kepemimpinan: Konsep, Teori, dan Karakternya.

Procedia - Social and Behavioral Sciences, 12(2), 10.

http://dx.doi.org/10.1016/j.intman.2016.11.002\%0Ahttps://doi.org/10.1016/j.tele.2

017.10.007\%0Ahttp://ilp.ut.ac.id/index.php/JOM/article/view/432\%0Ahttp://dx.doi .org/10.3926/jiem.1530\%0Ahttp://dx.doi.org/10.1016/j.bushor.2017.11.007\%0Aht tps://doi.org/10.10

Hakim, A. (2007). Entrepreneurship Membangun Spirit Teknopreneurship (1st ed.). ANDI.

Handaru, A. W., Pagita, M. P., \& Parimita, W. (2015). KARAKTERISTIK

ENTREPRENEUR MELALUI MULTIPLE DISKRIMINAN ANALISIS (Studi Pada

Etnis Tionghoa, Jawa dan Minang di Bekasi Utara). JRMSI - Jurnal Riset

Manajemen Sains Indonesia, 6(1), 351-375.

https://doi.org/10.21009/jrmsi.006.1.02

Henry, M. (1975). Matthew Henry's A Commentary on the Whole Bible. Flemming H.

Revell.

Pasande, P. (2020). Pemimpin dan Kepemimpinan Kristen.

https://doi.org/10.31219/osf.io/czydf

Steinhoff, D., \& Burgess, J. F. (1993). Small Business Management Fundamental. McGraw-Hill.

Suryana. (2013). Kewirausahaan: Kiat dan Proses Menuju Sukses. Salemba.

Tanasyah, Y., Iswahyudi, \& Phang, S. (2020). Membangun Kepepmimpinan Kristen

Entrepreneurial Sebagai Landasan Keberhasilan Upaya Memimpin.

QUAERENS: Journal of Theology and Christianity Studies, 2(2), 127-146.

https://doi.org/10.46362/quaerens.v2i1.1

Tomatala, Y. (2010). Spiritual Entrepreneurship: Anda Juga Bisa Menjadi

Entrepreneur Rohani. YT Leadership Foundation.

Wibowo, A. (2011). Pendidikan Kewirausahaan (Konsep dan Strategi). Pustaka

Pelajar.

Wijaya, Y. (2018). Kepemimpinan Yesus Sebagai Acuan Bagi Kepemimpinan Gereja

Masa Kini. Jurnal Jaffray, 16(2), 129. https://doi.org/10.25278/jj71.v16i2.287 
Winardi, J. (2015). Entrepreneur dan Entrepreneurship (4th ed.). Kencana.

Yunus, M. (2009). Islam dan Kewirausahaan Inovatif (1st ed.). UIN-Malang Press.

Zimmerer, T. W., \& Scarborough, N. M. (1996). Entrepreneurship and The New Venture Formation (1st ed.). Pearson College. 